\title{
Bir Yahudi Karşı-Geleneği Olarak Yahudi Sekülerliği: Kökenleri ve Dinamikleri
}

\author{
Salime Leyla Gürkan*
}

Seküler, sekülerleşme ve sekülarizm, birbiriyle bağlantılı fakat aynı zamanda birbirinden farklı vurguya sahip kavramlardır. Dünyevi veya profan manasına gelen Latince kökenli "seküler" (saecularis) kelimesi, "çağ" ya da "yüzyıl" manasına gelen, Hristiyan teolojisinde İsa Mesih'in göğe yükselişi ile insanlığın kurtuluşu için tekrar dünyaya dönüşü arasındaki dönemi, yani içinde yaşadığımız (profan) dünyayı ifade eden saeculum kelimesine dayanmaktadır. Bu kelime, mesihî ve bu dünya hayatını olumsuzlayan yapısı gereği bariz bir kutsal-profan ayrımı üzerine şekillenen Hristiyan geleneğinde, manastır düzenine bağlı olan rahiplerden farklı olarak toplum içinde hizmet veren rahipleri nitelemek için (clerus saecularis) kullanılmıştır. Sekülerleşme kelimesi ise ilk olarak siyasi anlamda, Avrupa'daki "Otuz Yıl Savaşları" diye bilinen din savaşlarının (1618-1648) ardından, kutsal alanı temsil eden kilisenin kontrolündeki mülkün seküler alanı temsil eden devletin kontrolüne geçmesini ifade etmek için kullanılmıştır. Buna karşılık başlangııından itibaren bu dünya merkezli ve bu dünyayı olumlayıcı vurguya sahip olan Yahudi geleneğinde, belli mekânlar (Kudüs ve Mabet bölgesi) veya kişiler (din adamı sınıfını oluşturan kohenler) daha fazla kutsallıkla ilişkilendirilmiş olsa da Hristiyanlık'taki gibi ontolojik bir kutsal-profan ayrımı ve buna paralel olarak kirli ve kurtarılmayı bekleyen dünya fikri yer almamıştır. Günümüz íbranicesinde seküler kelimesinin karşılığı olarak kullanılan hiloni kelimesi Eski Ahit İbranicesinde daha ziyade geçici bir kategoriye karşılık gelen ve ritüel anlamda kirliliği ya da eksikliği ifade eden hol (h-I-I) kelimesinden türetilmiştir (Biale, 2011, s. 4).

Modern dönemde daha sonra kazandığı mana itibariyle sosyal bir sürece karşılık gelen "sekülerleşme" genellikle, moderniteyle birlikte ortaya çıkan sanayileşme ve şehirleşme gibi sosyal-ekonomik değişimler ile kapitalizm ve milliyetçilik gibi akımlar yoluyla veya bu gelişmelere paralel olarak dinî inanış ve davranışlar ile dinî müesseselerin

* Doç. Dr., TDV İslâm Araştırmaları Merkezi.

Illetişim: salime.leyla@isam.org.tr. TDV ISAM, İcadiye Bağlarbaşı Cad. No: 40, Üsküdar, İstanbul.

- DOI: http://dx.doi.org/10.12658/human.society.2.4.R0006 
etki ve kontrol alanlarının azalması şeklinde tarif edilmektedir. Geç modern dönemde Hristiyan Avrupa, bilhassa Batı Avrupa toplumlarında ortaya çıkan sekülerleşme hareketi -ve seküler ideolojiler-, Hristiyan olmayan toplumlarda (Müslüman, Hindu vs.) ve Avrupa dışındaki coğrafyalarda da (Latin Amerika, Asya) farklı derecelerde etkili olmuştur. Daha ziyade 18. yüzyıl Aydınlanma düşüncesiyle ilişkilendirilen "sekülarizm" ise ferdî ahlakın ve sosyal -aynı zamanda siyasi, ekonomik ve kültürel- yapılanmanın temeli olarak dünyevi alanla sınırlı (din dışı veya din karşıtı) ilkeleri benimsemek suretiyle her çeşit tabiatüstü kavram ve vasıtaları reddeden, daha dar manasıyla din ve devletin ayrılığını öngören bir ideoloji ya da doktrin şeklinde tanımlanmaktadır (Wilson, 2005, s. 8214-15).

Talal Asad (2003, s. 1-2) tarafından işaret edildiği üzere, din-devlet ayrılığı ilkesi modern dönem öncesinde de (bazı Hristiyan ve Müslüman yönetimlerinde) uygulanmış olsa da modern manada sekülarizmi önceki örneklerden ayıran nokta, modern sekülarizmin din ve devlet ayrılığının ötesinde yeni bir "din", "ahlak" ve "siyaset" tanımı üzerine kurulmuş olmasıdır. Dolayısıyla modern dönem öncesinde seküler kavramı, din tarafından oluşturulmuş bir kategori olarak dinî otoritenin, yani kilisenin doğrudan alanına girmeyen (veya henüz girmemiş olan) "kutsal olmayan/profan alan"ı veya "kurtarılmayı bekleyen dünya"yı ifade edecek biçimde dinle bağlantılı bir kavrama karşılık gelirken modern dönemle birlikte Tanrı fikrinden tamamen soyutlanmış bir dünya tasavvuru karşılığında din karşıtı veya dini reddedici bir mana kazanmıştır (Biale, 2011, s. 2-3).

Felsefi ve siyasi bir ideoloji olarak 19. yüzyıldan itibaren kullanılmaya başlayan sekülarizm terimi, günümüz itibariyle daha ziyade sosyolojik bir mana içermektedir. Sekülarizm ile bununla bağlantılı bir diğer terim olan sekülerlik (secularity) arasında da ayrıma giden bir tanıma göre sekülarizm, sosyal-hukuki kurum ve yapılarla alakalı bir kavrama karşılık gelirken sekülerlik ise ferdî düzeyde kendini seküler olarak tanımlayan insanların düşünce/inanç ve hayat biçimlerini ifade etmek için kullanılmaktadır (Kosmin, 2007, s. 1). Bu makalede söz konusu ayrım dikkate alınmakla birlikte, kimi zaman sekülerlik ve sekülarizm birbirinin yerine geçecek şekilde kullanılacaktır. Yahudi sekülerliğinin gelenekle ve dinle bağlantısını çağdaş Yahudi yazarların tespitleri üzerinden ortaya koymayı amaçlayan bu makalenin ilk iki bölümünde, Yahudi sekülerliği üzerine kapsamlı çalışması olan David Biale'ın ilgili tezine dayanmak suretiyle, Yahudi sekülerliğinin Yahudi geleneğindeki muhtemel kökenleri ve bazı Orta Çağ Yahudi düşünürlerinin görüşlerinin bu süreçteki dolaylı rolü ele alınacak, son bölümde ise sekülerlik-din ilişkisi ekseninde günümüz Yahudi sekülerliğinin dinamiklerine vurgu yapılacaktır. 


\section{Yahudi Seküler Düşüncesinin Kökenleri: Sekülerlik-Gelenek Bağlantısı}

Hristiyan geleneği içinde ortaya çıkan sekülerleşmenin ve sekülarizmin Yahudiliğe, yani hem Yahudi düşüncesine hem de buna bağlı olarak Yahudi kimliğine ve pratiğine etkisi, Kuzey ve Doğu Avrupa kökenli, yani Aşkenaz geleneği temsil eden Avrupa Yahudi cemaatleri üzerinden gerçekleşmiştir. Dolayısıyla Yahudi sekülerliği, sonuç itibariyle Hristiyan Avrupa sekülerliğine paralel veya ona bağlı bir olgu olarak ortaya çıkmıştır. Fakat işin düşünce/teoloji boyutu ile pratik boyutu benzer süreçleri izlememiş; çeşitli yazarlar tarafından vurgulandığı üzere, Yahudi seküler düşüncesinin oluşumunda uzun zamana yayılan ve nispeten daha yumuşak bir geçiş söz konusu iken dinî pratiklerin terki noktasında değişim daha hızlı ve radikal olmuştur (Biale, 2008, s. 347; Siedman, 2011). Modern anlamda seküler düşünce, genellikle İspanya-Portekiz kökenli, yani Sefarad geleneğe mensup bir Yahudi heretiği olan Baruch -ya da mensup olduğu Amsterdam Yahudi cemaatinden kovulduktan sonraki ismiyle BenedictSpinoza (ö. 1677) ile başlatılmaktadır. Spinoza, ilk modern seküler düşünür, hatta ilk modern seküler "Yahudi" olarak da nitelendirilmektedir. Basit ifadeyle tabiatüstü alanı ve tabiatüstü Tanrı fikrini reddeden, onun yerine Tanrı'yı tabiatla eşitleyen (monizm) akılcı-tabiatçı düşünce biçimini savunan Spinoza'nın başlattığı seküler anlayış, daha sonra Yahudi geleneğinde Alman Yahudi düşünürü Solomon Maimon (ö. 1800) tarafından devam ettirilmiştir. Bu anlayışın bir ideolojiye dönüştüğü 19. yüzyıldan itibaren ise Theodore Herzl, Simon Dubnow, Moses Hess, Asher Ginsberg (Ahad Ha-Am), Hayim Bialik, Mordecai Kaplan gibi farklı seküler ideolojileri benimseyen Aşkenaz isimler yoluyla Yahudi düşüncesinde ve teolojisinde etkili bir unsur hâline gelmiştir. 20. yüzyılda sekülerliğin gerek düşünce gerekse hayat biçimi olarak dünya Yahudilerinin büyük bir kısmı tarafından benimsendiğini söylemek mümkündür. Bu tespit günümüzde de bilhassa ABD ve İsrail ile büyük ölçüde Avrupa Yahudileri için geçerli olmaktadır. Günümüz itibariyle Sefarad Yahudilerin çoğunluğu, başta İsrail'dekiler olmak üzere, dinî hükümlerden çok geleneğe ya da örfe bağlılık anlamında geleneksel tarz Yahudiliği benimserken katı biçimdeki seküler-dindar ayrımı daha ziyade Aşkenaz Yahudiler arasında görülmektedir.

Yukarıda işaret edildiği üzere, modern seküler düşüncenin ortaya çıkışı rasyonalist Aydınlanmacı düşünürlerle (Spinoza, Voltaire, Locke vs.) ilişkilendirilse de fikrî kökenleri Antik Yunan düşüncesine, bilhassa Epikür'e kadar götürülmekte, hatta bazı araştırmacılar tarafından, Orta Çağ döneminde yaşamış İbn Rüşd gibi Müslüman -ve İbn Meymun gibi Yahudi- düşünürlerin de bu sürece önemli katkıda bulunduğu kabul edilmektedir (ilgili değerlendirme için bk. Biale, 2008, s. 341). Bu noktada Oliver Leaman, İbn Rüşd'ün, felsefe ile dinin birbirine zıt, aslında zıt olmaktan ziyade farklı alanlara hitap eden birer hakikat olduğunu iddia eden bir düşünür olarak Batı'da kazandığı -hem aleyhte hem de lehte- şöhretin, onun sekülarizmin gelişiminde önemli rol oynadığı görüşünü doğruladığını belirtmektedir (Leaman, 1988, s. xv; 
2007). Öte yandan, Amerikan sosyolog Peter Berger ve Fransız tarihçi Marcel Gauchet, birbirinden bağımsız olarak ortaya koydukları tezlerinde, sekülerliğin esasen pagan çok tanrıcılığı ve putperestliğine karşı Tanrı́yı dünyadan soyutlayarak tek-aşkın varlık hâline getiren evrensel monoteist dinlerin doğuşuyla ortaya çıktığını ileri sürmüşlerdir. Modern anlamda sekülerliğin Protestan geleneği içinde ortaya çıktığına dikkat çeken Berger, sekülerliği Katolik gelenekle ilişkilendiren Gauchet gibi, bu süreçte bilhassa Eski Ahit monoteizminin önemli rol oynadığını savunmuştur (Biale, 2008, s. 341). Benzer şekilde David Biale, Yahudi seküler düşüncesinin kökenlerinin Orta Çağ Yahudi düşüncesinde, hatta kısmen de Rabbani ve daha ileri bir okumayla Eski Ahit geleneklerinde aranması gerektiğini ileri sürmektedir. Esasen Biale tarafından temas edildiği üzere (2008, s. 344), Orta Çağ Yahudi düşüncesinin de özellikle bu düşünceye damgasını vuran Sefarad Yahudi âlimler yoluyla, Antik Yunan düşüncesinin taşıyıcısı ve yorumlayıcısı olan dönemin İslam felsefesinden ve İslam kelamından etkilendiğini belirtmek gerekir. Fakat monoteizm ile sekülerlik arasında kurulan bağlantıya ihtiyatla yaklaşan Biale, sekülerliğin sadece monoteist gelenekle sınırlı olmadığı ve monoteist dinler içindeki tezahürünün de aynı olmadığına, buna karşılık farklı dinî geleneklerde de sekülerlik anlayışlarının ortaya çıktığı ve bu manada her seküler anlayışın kendi özel dinamiklerine sahip olduğuna dikkat çekmektedir. Biale'ın tezi, sekülerlik ile din arasındaki ilişkinin birbirini tamamen dışlayan "zıt kutupluk" yerine, birbirini besleyen -ve dönüştüren- "diyalektik karşılık" biçiminde anlaşılması gerektiği tespitinin altını çizmesi (2008, s. 340) ve bu diyalektik yapının, Yahudi sekülerliği ile Yahudi geleneği arasındaki ilişki için de geçerli olduğunu göstermesi bakımından önemlidir. Bu tespit, sanayileşme sürecini geçiren toplumların hepsinde dinin ortadan kalkacağını öngören klasik sekülerleşme teorisinin aksine, genel olarak dinin modernite ve sekülerlik karşısında farklı formlar (radikal, liberal vs.) geliştirerek ya da kendi içinde dönüşerek varlığını sürdürdüğü, hatta dinî bir canlanma yaşandığı gerçeğiyle ve aynı şekilde İsrail örneğinde görüldüğü üzere seküler Yahudilerin İsrail Yahudi nüfusunun yarısından fazlasını oluşturmasına rağmen belli Yahudi ritüellerinin \% 80-90 oranlarında uygulama alanı bulduğu gerçeğiyle birebir örtüşmektedir.

Biale'ın, Yahudi seküler düşüncesinin kökenlerine yönelik tezi, temel olarak Yahudi sekülarizminin Yahudi geleneğinden doğduğu, "Yahudi sekülerleri[nin] felsefelerini", dolaylı biçimde de olsa, "değiştirmeyi planladıkları dinî geleneğin [yani Yahudiliğin] üzerine inşa etti[kleri]" (Biale, 2008, s. 342) tespitine dayanmaktadır. Bu noktada Biale, sosyalist Yahudi yazar Isaac Deutscher'ın, "Yahudiliği aşan bir Yahudi heretiğ[in] Yahudi geleneğine ait" olduğu görüşünden hareketle, Yahudi sekülerliğini geleneğe karşı oluşturulan, ama daha az Yahudi olmayan bir "karşı-gelenek" (counter-tradition) şeklinde nitelemiştir. ${ }^{1}$

1 Biale, counter-tradition ifadesine makalesinde yer vermese de aynı başlığı taşıyan konferansında (Not in the Heavens: The Premoden Roots of Jewish Secularism. 2008 Posen Conference, Berkeley, 
Biale'a göre modern Yahudi seküler düşünürleri veya ideologları, bu seküler Yahudi -karşı- geleneğini oluştururken hem Yahudi geleneğine ait temel kavramları (Tanrı, Tevrat ve İsrail) hem de geleneksel Yahudi düşünürlerinin bir kısmının bu kavramlara uyguladığı metotları ödünç alıp kullanmış, fakat geleneksel düşünürlerden farklı olarak bunu dinî hedefler yerine seküler hedefler doğrultusunda yapmışlardır. Diğer bir ifadeyle kullanılan metot ve kısmen de kavramlar -bilinçli olarak veya olmayarak-aynı kalırken içerik ve hedef bilinçli olarak değişime uğramıştır. Tanrı'nın yerini -kimi zaman bizzat Tanrı'yla özdeşleştirilen ya da kendisine Tanrılık fonksiyonu yüklenen- "tabiat" almış; Tevrat, Yahudiliğin dinî kodları yerine "kültürel ve tarihî" kodlarını oluşturacak şekilde yeniden yorumlanmış; İsrail ise kutsal ahit topluluğu yerine "siyasi ve etnik bir millet" konumuna getirilmiştir (Biale, 2008, s. 344).

Bu noktada ilginç olan bir diğer husus ise Yahudi sekülerliğinin öncü isimlerini Aşkenaz Yahudi düşünürlerin oluşturmasına karşılık, Biale'ın ifadesiyle, babalarının temsil ettiği geleneğe karşı isyan bayrağı açan bu seküler Aşkenaz "oğullar"ın seküler başkaldırılarını ve buna yönelik dönüşümü gerçekleştirirken büyük "amcaları" olan Sefarad Yahudileri'nin fikirlerinden istifade etmiş olmalarıdır (Biale, 2008, s. 344). Söz konusu Sefarad Yahudilerinin başında da Orta Çağ Yahudi düşüncesinin en önemli isimlerinden olan ve her ikisi de -Yahudi Altın Çağı'na tanıklık eden- Endülüs Yahudi cemaati içinde yetişmiş Musa ibn Meymun (ö. 1204) ve Abraham ibn Ezra (ö. 1164) gelmektedir. Dolayısıyla Aşkenaz Yahudilik içinden çıkan Yahudi sekülerliğinin ilk tohumlarının, kendisi de bir Sefarad Yahudisi olan ve modern seküler düşünce açısından dönüm noktası oluşturan Spinoza'yı da önceleyecek şekilde, modern dönem öncesi Sefarad düşünce geleneğinde atıldığı iddia edilmektedir.

\section{Spinoza'nın Fikrî Öncüleri: İbn Meymun ve İbn Ezra}

Biale, modern Yahudi seküler düşüncesinin ve aynı zamanda Spinoza'nın fikrî öncüleri olarak İbn Meymun ve İbn Ezra gibi Orta Çağ Yahudi âlimlerini adres gösterirken söz konusu âlimlerin ortaya koydukları fikirlerin "bilinçli" olarak sekülerliğe kapı aralamadığı ya da bu amaçla ortaya konmadığı gerçeğinin altını çizmektedir ki zaten böyle bir iddia kendinde anakronik bir iddia olacaktır (Biale, 2008, s. 343). Fakat bu fikirler sekülerliğe dolaylı olarak kapı aralarken kendi dönemlerinde bile, karşı-gelenek oluşturacak derecede olmasa bile, radikal sayılabilecek ve tabii olarak modern dönemde çok daha radikal yorumları mümkün kılacak unsurlar içermiştir (Biale, 2008, s. 347). ${ }^{2}$

California) ve daha sonra basılan kitabının (Not in the Heavens: The Tradition of Jewish Secular Thought, 2011) ilk tasarlanan alt başlığında (The Counter-Tradition of Jewish Secular Thought) bu ifadeyi kullanmıştır; krş. Biale, 2008, s. 342. Biale'ın daha sonra terk ettiği görülen bu ifadeyi, Yahudi sekülerliğinin Yahudi geleneğiyle ilişkisini vurgulaması açısından burada bilhassa kullanmayı tercih ettim. 
Biale'a göre, bu unsurlardan en önemlileri Tanrı ve Tevrat anlayışlarıyla ilgili olup İbn Meymun tarafından seslendirilen "negatif teoloji" ile yine İbn Meymun'un ve İbn Ezra'nın ortaya koyduğu, sırasıyla, "tarihselci" ve "pedagojik" Tevrat okumalarıdır. Bir diğer önemli unsur da cemaat olarak İsrail üzerinden oluşturulan siyaset teorisidir.

Bu görüşleri temel noktalarından hareketle ele almak gerekirse, ilk olarak İbn Meymun'un Delâletü'I-hâirin'de (I, 51-59) Tanrı'yı olumsuzlama yoluyla tanımlaması -ki bunda Tanrı'ya sadece olumsuz sıfatlar atfedilebileceğini ileri süren Mutezile kelamının etkisi barizdir-Spinoza'nın savunduğu Tanrı fikrinin de temelini oluşturmuştur. İbn Meymun'un, Tanah'ın antropomorfik nitelikler taşıyan şahsi Tanrısının tam aksine, sadece "fiilî sıfatları, yani [bu sıfatların sonucu olan] tabii dünya" yoluyla bilinebileceğini ileri sürdüğü son derece soyut ve "aşkın Tanrı" fikri, bir diğer zıt radikal anlayışı, yani Spinoza'nın bir öze ya da ilkeye indirgemek suretiyle tabiata ya da evrene eşitlediği tamamen "içkin Tanrı" fikrini doğurmuştur -ki bu da esasen Kabala öğretisine ait panteist bir çıkarımı çağrıştırmaktadır (Biale, 2008, s. 347; Spinoza'nın Tanrı anlayışı için bk. Spinoza, 1954. Kabalacı panenteist Tanrı anlayışı için ayrıca bk. Scholem, 1995, s. 252-25; Jacobs, 1973, s. 43-44). Bir Fransız aforizmasında ifade edildiği gibi (Un Dieu defini serait un Dieu fini), tanımlanan bir Tanrı'nın sonlu bir Tanrı olduğu -yani aslında Tanrı olmadığı- doğrudur; buna karşılık, Biale tarafından işaret edildiği üzere, tanımlanamayan bir Tanrı da (İbn Meymun'un Tanrısı) gerçekte var olmayan bir Tanrı (Spinoza'nın Tanrısı) sonucuna götürmektedir (Biale, 2008, s. 348). ${ }^{3}$

Biale'ın işaret ettiği ikinci husus, "kutsal metin tenkidini sekülerleştirmede önemli rol oyna[dığını]" iddia ettiği, dönemi açısından radikal ya da aykırı kabul edilebilecek Tevrat okumalarına yöneliktir. Bu okumalardan ilki, Orta Çağ’ın en önemli Tevrat müfessirlerinden İbn Ezra'ya aittir. İbn Ezra, Tevrat hükümlerinin akli olan her şeye zıt olduğunu ve hiçbir hakikat içermediğini ileri süren 9. yüzyıl İranlı Yahudi âlimi Hivi el-Belhi'nin görüşlerini tenkit etse de kendisi de Tevrat'la ilgili bazı radikal tespitlerde bulunmaktan geri durmamıştır. Her şeyden önce, modern dönemde ortaya konan kutsal metin tenkidine malzeme oluşturacak şekilde, Tevrat'ın Hz. Musa'ya ait olmayan bazı pasajlar içerdiği görüşünü ilk defa seslendiren kişi İbn Ezra'dır. Ayrıca, Saadya Gaon'un başlatmış olduğu alegorik yorum tekniğini kullanarak Tevrat'ı bilim ve felsefeyle uyuşturma tavrını hem dinî hem de ilmî alana haksızlık yaptığı gerekçesiyle reddeden İbn Ezra, bunun yerine lafzi yorumlama biçimini esas alarak Tevrat'ın felsefi değil, günlük ve sıradan bir insan dili kullandığını, dolayısıyla hiçbir bilimsel bilgi içer-

ri tarafından İbn Meymun'un felsefi yazılarının okunmasının yasaklandığını, buna karşılık aynı İbn Meymun'un modern dönemde hem seküler hem dindar kesimlerde en önemli referans kaynağı kabul edildiğini belirtmek gerekir.

3 Spinoza'nın Tanrısı'ndan hareketle gelenek karşıtı teoloji geliştiren modern Yahudi düşünürlerinin başında Solomon Maimon, Hermann Cohen, Heinrich Heine ve Mordecai Kaplan gelmektedir (Biale, 2008, s. 350-351). 
meyip sadece pedagojik bilgi içerdiğini ileri sürmüştür. Diğer bir deyişle, Tevrat ifadelerine hakikat atfetmekle birlikte, bunu gündelik alanla sınırlandırmıştır. Bu şekilde bilimi ve vahyi birbirinden ayırmak suretiyle tabiatı dinden bağımsız bir alan hâline getirmiştir. Biale'ın, metot itibariyle değilse bile sonuçları itibariyle İbn Ezra'nın pedagojik Tevrat anlayışına paralel gördüğü bir diğer radikal Tevrat okuması da İbn Meymun'un felsefi-alegorik ve -fakat- tarihselci okumasıdır. İbn Meymun'un Delâletü'l-hâirin'de (III, 19), Tanrı'nın kurban uygulamasını İsrailoğulları'nı putperestlikten uzaklaştırmak için ve dolayısıyla fonksiyonunu gerçekleştirdiğinde kendi kendine ortadan kalkacak şekilde tesis ettiğini ima etmesi, bu tarihselci bakış açısının modern dönemde seküler Yahudiler tarafından bütün bir Yahudi ibadetine ya da pratiğine uygulanmasına kapı aralamıştır (Biale, 2008, s. 353).

Nitekim bu yorumların uzantılarını hem Spinoza'da hem de Aydınlanmacı Yahudi düşünürlerinde bulmak mümkündür. İbn Ezra'nın, bazı Tevrat pasajlarına yönelik tespitini bir ileri noktaya taşıyarak Tevrat'ın Musa'ya değil, Ezra'ya ait bir kitap olduğunu savunan Spinoza, yine İbn Ezra'nın yorumuna benzer şekilde, Tevrat'ın İsrailoğulları'nın siyasi tarihinden ibaret olduğunu, dolayısıyla dinî ya da felsefi değil, tarihî bir metin olarak değer taşıdığını ileri sürmüştür. Bu şekilde Spinoza, İbn Ezra ve İbn Meymun'un başlattığı radikal yorumları en uç noktasına taşıyarak tüm Tanah'ı özellikle de Tevrat'ı bir vahiy ve kutsal metin konumundan çıkarıp tarihî ve siyasi bir metin konumuna getirmiş, böylece teoloji-dışı bir dizi modern ve seküler okumaya -sosyalizm, nasyonalism vs.- kapı aralamıştır. Bunun sonucunda, Rabbani Tevratı́nın yerini alan "kültürel Tevrat, din yerine kültüre dayanan Yahudi kimliğine yönelik yeni tanımlamalar[a]" temel oluşturmuştur (Biale, 2008, s. 355-356; Spinoza'nın görüşleri için bk. Spinoza, 1991, 8. bölüm). Benzer şekilde Yahudi Aydınlanması'nın öncülerinden olan Moses Mendelssohn da Tevrat'ın ve dolayısıyla Yahudiliğin evrensel hakikat değil, sadece Yahudilere yönelik bir hukuk/şeriat içerdiğini, Yahudilerin özel hayatlarını ilgilendiren bu ritüelin de uygulama noktasında zorlamaya değil ferdî isteğe dayandığını ileri sürerek (Mendelssohn, 1983, s. 90-91, 126-130) kolayca sekülerliğe evrilebilecek ferdî ve liberal bir Yahudilik anlayışı geliştirmiştir.

Biale'ın vurguladığı üçüncü husus ise topluluk olarak İsrail'e yüklenen fonksiyonla alakalıdır. Bu noktada Biale, daha önce sadece Rabbani mahkemelerinin sahip olduğu merkezî hukuki otoritenin Orta Çağ teorisyenleri tarafından -özellikle kamuyu ilgilendiren konularda- tüm cemaati kapsayacak şekilde genişletildiği ve bunu yaparken de "sosyal kontrat dili"nin kullanıldığına; bunun sonucunda "Orta Çağ Yahudi siyaset teorisi[nin] Kitab-ı Mukaddes'e dayanan köklerinden uzaklaşarak seküler dile dayanan cemaat idaresini mümkün kıl[dığına]" işaret etmektedir (Biale, 2008, s. 356-357). İbn Meymun'un bu teoriye katkısı bağlamında ise "zamanın gerekleri" kavramı doğrultusunda (seküler) kralların/yöneticilerin yetkisini kabul etmesini ve bu şekilde ilahî hükme alternatif olarak seküler siyasete zemin hazırlamış olmasını zikretmektedir. Modern 
seküler siyasete götüren süreçte Biale'ın zikrettiği diğer isimler ise Nahmanides (Tevrat hukuk sistemi dışında yürürlüğe konan yerel âdetlerin ve cemaat kurallarının meşruiyeti), Şilomo ibn Adret (Tevrat'ta yasaklanmış olsa da toplumun muhafazası için güç kullanılabileceği) ve Nissim Gerondi'dir (toplumu korumaya yönelik kuralların geçici olmayıp Tevrat'ı tamamlayıcı bir hukuk sistemi oluşturduğu) (Biale, 2008, s. 357).

Bu anlayışların modern uzantısı olarak Biale, sırasıyla, Spinoza'ya ve Hess'e atıf yapmaktadır. Yahudilerin dinî -veya etnik- değil, siyasi bir cemaat oluşturduğunu ileri süren Spinoza, İsrailoğullarının Hz. Musa döneminde, sosyal kontrat görevi gören ahit yoluyla, gerçek iktidarın topluma ait olduğu, Tanrı́nın ise toplum adına sanal iktidarı temsil ettiği bir devlet modelini hayata geçirdiğini ileri sürmüş; buradan hareketle, Eski Ahit'in, Tanrı fikri aradan çıkarıldığı takdirde, modern anlamda bir devlet modeline, yani "dinin sadece ahlaki yönlendirme görevi göreceği, devlet işlerininse devlete bırakılacağı bir yönetim[e]" ilham kaynağı oluşturacağını savunmuştur (Biale, 2008, s. 358; Spinoza'nın ilgili görüşleri için bk. Spinoza, 1991, 17-19. bölümler). Öte yandan, Spinoza'nın seslendirdiği, Yahudilerin siyasi bir topluluk olduğu ve devlet olma özelliğini kaybetmeleriyle birlikte Yahudi kimliğinin de zeminini kaybettiği şeklindeki görüş, Siyonizmin öncülerinden Hess'e ilham kaynağı oluşturmuştur. Hess ve diğer Siyonistler için Yahudiler -Spinoza'nın görüşünün aksine- bir ırka karşılık gelse de Yahudilerin yeniden fakat bu sefer modern ve seküler anlamda bir millet olması için siyasi bağımsızlıklarını elde etmeleri, yani bir devlete sahip olmaları fikri Spinoza'nın görüşlerine dayanmıştır (Biale, 2008, s. 359-360).

\section{Günümüz Seküler Yahudiliğinin Dinamikleri: Sekülerlik-Din İlişkisi}

Biale'ın tüm bu açıklamalar doğrultusunda vardığı sonuç, Yahudi sekülerliği “metafizik, tarihî ve siyasi doktrinleri açısından modern bir gelişme olsa da köklerinin kadim felsefi ve dinî toprağa uzandı[ğı]" (Biale, 2008, s. 360) ve farkında olarak veya olmayarak bu topraktan beslendiği şeklindedir. Biale'ın bu panoramik tespitini akılda tutarak bilhassa günümüz itibariyle seküler Yahudiliğin dinamiklerine bakmak gerekirse, her şeyden önce tek bir Yahudi seküler anlayışının olmadığı ve bütün sekülerlik anlayışlarının da din karşıtı olmadığı tespitinin (Mendes-Flohr, 2012, s. 4) altını çizmekte fayda var. Bilhassa $A B D$ 'de kendini seküler olarak tanımlayanların oranı diğer etnik/dinî gruplara göre Yahudi kesim içinde daha fazla ve yine Tanrı inancına sahip olmayanların seküler Yahudi kesimdeki oranı diğer seküler gruplara nispetle daha yüksek olmasına rağmen (sekülerlik oranı Amerikan Yahudilerinde \% 48, Britanyalı Yahudilerde \% 58, İsrail Yahudilerinde ise \% 59), seküler Yahudilerin hepsi inançsız değildir (Gordis, 2012, s. 36-40; Kosmin, 2012, s. 20-35). Dolayısıyla genel olarak Yahudi toplumundaki -dindardan sekülere uzanan- çeşitlilik kısmen Yahudi seküler toplumu için de geçerli olmaktadır. Paul Mendes-Flohr (2012, s. 4) tarafından işaret edildiği üzere, bu çeşitli- 
liğe karşılık Yahudi sekülerliğinin ortak noktası, Yahudi öz tanımlamasının belirleyicisi olarak geleneğin ya da dinin değil, alternatif (etnik, ideolojik veya kültürel) unsurların esas alınmasıdır (sosyalizm, hümanizm, Siyonizm vs.). Zira sekülerlikle birlikte "Yahudi öz-tanımlaması teolojiden sosyolojiye ve hatta psikolojiye kaymakta", daha önce geleneksel Yahudiler tarafından cevap aranan soru "Yahudi varlığının teolojik manası nedir?" iken bunun yerine modern Yahudiler tarafından "Neden Yahudiyim?" sorusu sorulmaktadır (Mendes-Flohr, 2012, s. 6). Yahudi kimliği, içerdiği etnik unsur, yani Yahudilerin dinle birlikte ortaya çıkmış ve var olmuş bir topluluk olması dolayısıyla, modern dönemde dinin devre dışı bırakılmasıyla birlikte, Yahudi olmanın manasına yönelik böyle bir sorgulamayı mümkün hatta gerekli kılmaktadır.

Fakat Biale'ın önceki tespitine atıfla, seküler Yahudiler, Yahudi geleneğini aşmakla veya dışlamakla Yahudi olmaktan çıkmadıkları gibi Yahudiliğin dışına da çıkmış olmamaktadır. Avi Sagi tarafından işaret edildiği üzere, dindar Yahudiler açısından din içermeyen bir Yahudi varlığı hem anlamsız hem de tehlikeli görülse de ${ }^{4}$ seküler Yahudiler için seküler Yahudilik sadece negatif anlamda geleneğin reddine dayanmamakta, aynı zamanda pozitif anlamda "Yahudi varlığının bir alternatifini önermektedir" (Sagi, 2006, s. 119). Fakat bunu yaparken Yahudi dini, yani Yahudiliğin dinî gelenek boyutu yerine, tarihî ve kültürel boyutları dikkate alınmaktadır (Sagi, 2006, s. 110). Dolayısıyla seküler Yahudiler için kendilerinin temsil ettiği seküler Yahudilik "daha az" Yahudiliği değil, bilakis "daha doğru, daha bilimsel ve daha tarihsel Yahudiliği" (Sagi, 2006, s. 116) ifade etmektedir. Bu sebeple, seküler Yahudiler genel olarak Yahudiliğe ya da Yahudi kimliğine karşı duyarsız olmakla suçlansa da giderek daha fazla sayıda seküler Yahudi, kendilerine Yahudilik içinde seküler kimlikleriyle (meşru) bir alan açma amacıyla kendilerini büyük harfle Seküler ya da Seküler Hümanist Yahudi biçiminde tanımlamaktadır (Goldfinger, 2012, s. 117).

Yine Amerikan Yahudileri üzerine gerçekleştirilen bir ankette, kendilerini kısmen veya tamamen seküler olarak tanımlayan Yahudiler içinde Tanrı ile ilgili sorulara (Tanrı́nın varlığı, duaları işitmesi, yardım etmesi, mucize göstermesi vs.) olumlu cevap verenlerin oranı, diğer seküler gruplara göre daha düşük olsa da seküler Yahudilerin azınsanmayacak bir kısmının (ortalama \% 50 civarı), gelenekten ve kurumsal Yahudilikten kopsalar bile maneviyattan -Tanrı merkezli olmaktan çok ben merkezli bir maneviyattan- tamamen yoksun olmadıklarını göstermektedir (ilgili istatistik ve değerlendirme için bk. Gordis, 2012, s. 36-40). İsrail'deki seküler Yahudilerin önemli bir kısmının, kültürel sebeplerle veya milliyetçilik adına da olsa belli Yahudi ritüellerine iştiraki de işin diğer bir boyutuna karşılık gelmektedir (geniş bilgi için bk. Yadgar, 2011). Sekülerliğin en fazla oranda seyrettiği bu iki Yahudi toplumu arasındaki önemli bir fark ise çoğul-

4 Seküler Yahudiliğin içerdiği dezavantajlar (verili muhteva ile dinî-evrensel içeriğin eksikliğinden kaynaklanan, sırasıyla, 'kimlik çözülmesi riski' ve 'etnik şovenizme düşme tehlikesi') üzerine bir değerlendirme için bk. Mendes-Flohr, 2012, s. 7, 13. 
culuğun bir norm olarak benimsendiği Amerikan Yahudiliği için asıl sorun, kurumsal Yahudiliğin çoğu Yahudiye hitap etmiyor olması iken çoğulculuk anlayışının henüz tam olarak yerleşmediği İsrail Yahudiliği açısından en önemli sorunu ise seküler ve dindar kesimler arasındaki kutuplaşma oluşturmaktadır.

Dolayısıyla, sekülerlik üzerine yapılan tartışmalarda da dile getirildiği üzere, kompleks bir sekülerlik-gelenek/din bağlantısından hareketle, genel olarak günümüz Yahudiliği açısından cevaplanmayı bekleyen soru, farklılığın gerilimli de olsa bir zenginlik mi yoksa fiziki/manevi açıdan bir tehdit mi olarak anlaşılması gerektiğine yönelik olmaktadır. Aslında bu sorunun cevabı da büyük ölçüde Yahudiliğin ne olarak anlaşılması gerektiği, yani bir din mi etnisite mi ya da dinî-etnik bir kültür mü olduğu sorusuyla bağlantılı olmaktadır.

\section{Kaynakça}

Asad, T. (2003). Formations of the secular: Christianity, Islam, modernity. Stanford, CA: Stanford University Press.

Biale, D. (2008). Not in the heavens: The premoden roots of Jewish secularism. Religion Compass, 2(3), 340-364.

Biale, D. (2011). Not in the Heavens: The tradition of Jewish secular thought. Princeton: Princeton University Press.

Goldfinger, E. (2012). Accepting secular Jewishness and embracing all Jews. In D. M. Gordis, \& Z. I. Heler (Eds.), Jewish secularity: The Search for roots and the challenges of relevant meaning (pp. 115-123). New York: University Press of America.

Gordis, D. M. (2012). Secularism in the contemporary Jewish community. In D. M. Gordis, \& Z. I. Heler (Eds.), Jewish secularity: The Search for roots and the challenges of relevant meaning (pp. 36-40). New York: University Press of America.

Jacobs, L. (1973). A Jewish theology. West Orange, NJ: Behrman House.

Kosmin, B. A. (2007). Contemporary secularism and secularity. In B. A. Kosmin, \& A. Keysar (Eds.), Secularism and secularity: Contemporary international perspectives (pp. 1-13). Hartford, CT: Institute for the Study of Secularism in Society and Culture, Trinity College.

Kosmin, B. A. (2012). Demography and dimensions of secularity among American Jews. In D. M. Gordis, \& Z. I. Heler (Eds.), Jewish secularity: The Search for roots and the challenges of relevant meaning (pp. 20-35). New York: University Press of America.

Leaman, O. (1988). Averroes and his philosophy. Surrey: Curzon.

Leaman, O. (2007, September). Rethinking Islamic philosophy and theology. N. Muhtaroğlu (interview). Fountain Magazine, 59, Retrieved November 19, 2012, from http://www.fountainmagazine.com/Issue/ detail/Rethinking-Islamic-Philosophy-and-Theology

Mendelssohn, M. (1983). Jerusalem: Or on religious power and Judaism (trans. A. Arkush), Hanover/ London: Brandeis University Press.

Mendes-Flohr, P. (2012). Secular forms of Jewishness. In D. M. Gordis, \& Z. I. Heler (Eds.), Jewish secularity: The search for roots and the challenges of relevant meaning (pp. 4-19). New York: University Press of America. 
Sagi, A. (2006). On religious-secular tensions. In E. Ben-Rafael, T. Gergely, \& Y. Gorny (Eds.), Jewry between tradition and secularism: Europe and Israel compared (pp. 115-120). Leiden/Boston: Brill.

Scholem, G. (1995). Major trends in Jewish mysticism. New York: Schocken Books.

Siedman, N. (2011). Jewish secularism: Secularization and sexuality. Paper presented the University for a Day on Jewish Secularism, The New School Conference. Retrieved November 21, 2012, from http:// www.youtube.com/watch?v=x72Wbt7omi8\&feature=relmfu

Spinoza, B. (1954). Ethics and on the improvement of the understanding (Ed. J. Guttman). New York: Hafner Publishing Company.

Spinoza, B. (1991). Tractatus theologico-politicus (trans. S. Shirley). Leiden/New York: E.J. Brill.

Yadgar, Y. (2011). Secularism and religion in Jewish-Israeli politics: Traditionists and modernity. London/ New York: Routledge.

Wilson, B. R. (2005). Secularization. In Encyclopedia of Religion (2nd edt., Vol. 12, s. 8214-15). New York: Macmillan Reference USA. 